\title{
Flow cytometric determination of phytoplankton DNA in cultures and oceanic populations
}

\author{
Nicolas Boucher*, Daniel Vaulot**, Frédéric Partensky*** \\ CNRS et Université de Paris 6, Station Biologique BP 74, F-29682 Roscoff Cédex, France
}

\begin{abstract}
A method to measure DNA and chlorophyll fluorescence simultaneously in single phytoplankton cells was developed and tested on cultured and natural populations. Samples were stored at $-80^{\circ} \mathrm{C}$ following fixation with $1 \%$ glutaraldehyde and freezing in liquid nitrogen, stained with DAPI $\left(4^{\prime}, 6\right.$-diamino-2-phenylindole $)$, and analyzed by flow cytometry. In cultures, cell DAPI-DNA fluorescence measured by flow cytometry was related to cell DNA content measured by fluorometry with DAPI, over almost 4 orders of magnitude. In natural populations, the method easily discriminated photosynthetic cells from other living and non-living particles and permitted computation of the fraction of particulate DNA contained in photosynthetic picoplankton. In the northwestern Mediterranean Sea in summer, this fraction was higher at neritic than at pelagic stations, and at the latter was maximum at mid-depth. In the future, this method should permit (1) better estimates of biomass partitioning among the different trophic compartments, and (2) studies of cell cycling of oceanic plankton populations.
\end{abstract}

\section{INTRODUCTION}

DNA is the most significant biological molecule on Earth because it encodes all living processes. Despite its small contribution to marine organic matter (ca $5 \%$ of 'particulate' and $0.1 \%$ of 'dissolved' organic carbon, respectively; Paul et al. 1985, 1988), it is an important biogeochemical marker which has been relatively little studied in aquatic environments (e.g. Holm-Hansen et al. 1968, Holm-Hansen 1969b, Pillai \& Ganguly 1972, Falkowski \& Owens 1982, Dortch et al. 1983, Paul et al. 1985, 1988, Winn \& Karl 1986, Karl \& Bailliff 1989).

In contrast to other cellular constituents, which vary widely with growth conditions, DNA content of a given cell type varies within a narrow range, typically 2 -fold in extent for eukaryotes, with extremes reached at the beginning $\left(G_{1}\right.$ phase $)$ and end $\left(G_{2}\right.$ phase $)$ of the cell

- Present address: Department of Biological Sciences, University of California at Santa Barbara, Santa Barbara, California 93106, USA

- Addressee for reprint requests (Roscoff). On temporary leave at: Oceanography Department, University of Hawaii, 1000 Pope Road, Honolulu, Hawaii 96822, USA

- On temporary leave at: Biological Oceanography Division, Bedford Institute of Oceanography, Dartmouth, Nova Scotia, Canada B2Y 4A2 cycle (Prescott 1976). Therefore, it has been hypothesized that particulate DNA concentrations could be used to provide reasonable estimates of living biomass (Holm-Hansen et al. 1968, Dortch et al. 1983). Indeed, cell DNA was found to be linearly related to cell carbon for a variety of phytoplankton species (Holm-Hansen 1969a). The failure of initial attempts (Holm-Hansen 1969b) to reconcile biomass estimates from DNA, on the one hand, and from particulate carbon, chlorophyll, or ATP, on the other hand, was attributed to the presence of an important fraction of 'detrital' DNA. This assertion has been challenged recently, at least in the case of coastal waters (Falkowski \& Owens 1982, Dortch et al. 1983). Paul et al. (1985) found that particulate DNA was actually closely correlated with particulate organic carbon (POC) and bacterial counts in a wide range of environments. Winn $\&$ Karl (1986) noted, however, that only 10 to $25 \%$ of the particulate DNA appeared to be replicating actively in Pacific oligotrophic waters.

Some of the contradictions among these studies can be ascribed to the use of conversion factors (e.g. between carbon and DNA, carbon and ATP) that are assumed to apply universally to all compartments of the food web. This assumption might not hold, as recent measurements (Simon \& Azam 1989) show that the DNA: carbon ratio is higher in bacteria than in phytoplankton and, for the former, decreases as cell size 
increases. Therefore, in order to obtain better biomass estimates from DNA and to solve the riddle of 'detrital' DNA, it appears necessary to separate the contribution of the different communities to particulate DNA. One way to achieve this result is to perform filter-fractionation: Paul et al. (1985) have shown that in the Gulf of Mexico, between 70 and $99 \%$ of the particulate DNA is contained in the 0.2 to $1 \mu \mathrm{m}$ fraction, suggesting that bacteria dominate in particulate DNA, at least in pelagic waters. However, the complexity of the microbial loop and the interpenetration between the sizeclasses of autotrophs and heterotrophs (as evidenced by the recent discovery of bacteria-sized primary producers, Chisholm et al. 1988) singularly complicate interpretation of such measurements.

A potential solution is to measure DNA in single cells. This may be easily done by flow cytometry, which also discriminates autotrophs from other cell types in natural populations, using the red chlorophyll fluorescence of the former (Olson et al. 1985), and is very sensitive since it has been used recently for bacterial DNA determination in aquatic samples (Robertson \& Button 1989).

In the present paper, we describe a flow cytometric method to measure quantitatively DNA in natural phytoplankton populations, which is calibrated with bulk fluorometric DNA determinations performed on a set of phytoplankton strains. The method is applied to estimate the fraction of particulate DNA contained in photosynthetic picoplankton in the northwestern Mediterranean Sea in summer.

\section{MATERIAL AND METHODS}

Cultured species. Eleven non-axenic phytoplankton strains belonging to 6 algal classes and representing a wide range of algal cell sizes (Table 1) were grown in either K (Keller et al. 1987) or f/2 (Guillard \& Ryther
1962) medium. Batch cultures were maintained at $20^{\circ} \mathrm{C}$

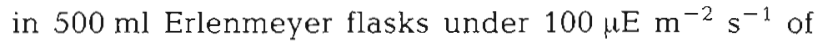
fluorescent light (Sylvania F58 WI-154ST) supplied on a $12 \mathrm{~h}$ light: $12 \mathrm{~h}$ dark cycle. Cultures were sampled in late exponential phase to maximize yield and minimize bacterial contamination.

Field samples. Four stations were sampled with Niskin bottles at 4 to 6 levels depending on bottom depth during the EROS-2000 cruise of the Italian RV 'Bannock' in the northwestern Mediterranean Sea between 1 July and 15 July 1989

Cell densities and size. For cultures, replicate $(n>4)$ measurements were made on $0.5 \mathrm{ml}$ samples using a Coulter Counter (model ZM, Coulter, Hialeah, Florida) equipped with a $100 \mu \mathrm{m}$ diameter orifice and coupled to a logarithm range expander and a C1000 Channelyser. Since Synechococcus spp. are too small to be sized accurately with the $100 \mu \mathrm{m}$ orifice, their abundance was determined by flow cytometry (see below) on replicate $100 \mu$ samples $(n>4)$.

Particulate DNA. DNA was quantified using the method developed by Brunk et al. (1979) and modified by Falkowsky \& Owens (1982). In brief, samples of cultured (20 to $50 \mathrm{ml}$ ) or natural $(350 \mathrm{ml})$ populations were gently $(<100 \mathrm{~mm} \mathrm{Hg})$ filtered onto Whatman $\mathrm{GF} / \mathrm{F}$ filters washed with a $3 \% \mathrm{NaCl}, 10 \mathrm{mM}$ EDTA solution. When the analysis could not be performed immediately (e.g. natural samples), filters were frozen in liquid nitrogen and stored at $-80^{\circ} \mathrm{C}$. Filters were homogenized on ice in $2 \mathrm{ml}$ of a solution (A) containing $100 \mathrm{mM} \mathrm{NaCl}\left(5.85 \mathrm{~g} \mathrm{l}^{-1}\right), 10 \mathrm{mM}$ EDTA $\left(3.35 \mathrm{~g} \mathrm{l}^{-1}\right.$ ) and $100 \mathrm{mM}$ Tris $\left(12.1 \mathrm{~g} \mathrm{I}^{-1}\right)$ at $\mathrm{pH} 7$. The slurry was centrifuged $5 \mathrm{~min}$ at $1500 \mathrm{rpm}$. The DNA-containing supernatant was kept at $4{ }^{\circ} \mathrm{C}$ until analysis, which was routinely performed within $3 \mathrm{~h}$.

Stock solutions of DAPI $\left(4^{\prime}, 6\right.$-diamino-2-phenylindole, mol. wt $=279$; Sigma, St. Louis, Missouri, D1388) were prepared in solution $A$ at a final concentration of $100 \mathrm{ng} \mathrm{ml}^{-1}(0.36 \mu \mathrm{M})$. Standard DNA stock solution

Table 1. Cultured algal species used in this study

\begin{tabular}{|llll|}
\hline Class & \multicolumn{1}{c}{ Species } & Strain & Laboratory of origin \\
\hline Cyanophyceae & Synechococcus sp. & ROS04 & Roscoff (France) \\
& Synechococcus sp. & WH7803 & CCMP-Bigelow (USA) \\
Cryptophyceae & Cryptomonas maculata & & Plymouth (UK) \\
Dinophyceae & Amphidinium carteri & CCMP-Bigelow (USA) \\
& Gymnodinium cf. nagasakiense & Tinduff & Roscoff (France) \\
Prymnesiophyceae & Gymnodinium nagasakiense & Buzen- $85-2$ & Kitasato (Japan) \\
& Isochrysis galbana & Iso & L'Houmeau (France) \\
Bymenomonas carterae & Coccoli & CCMP-Bigelow (USA) \\
Chlorophyceae & Phaeocystis pouchetii & & Texel (Netherlands) \\
& Thalassiosira weissflogii & Actin & CCMP-Bigelow (USA) \\
\hline
\end{tabular}


(final concentration $20 \mu \mathrm{g} \mathrm{ml}^{-1}$ ) was obtained by dissolving calf thymus DNA (Sigma Type I, D1501) at room temperature in solution $\mathrm{A}(\mathrm{pH}=10)$ and adjusting to $\mathrm{pH} 7$ with Tris- $\mathrm{HCl}$.

Fluorescence measurements (excitation $=350 \mathrm{~nm}$; emission $=460 \mathrm{~nm}$ ) were performed on a JY3D spectrofluorometer (Jobin et Yvon, France) equipped with a $150 \mathrm{~W}$ xenon light source, and DNA concentration was computed as detailed in Falkowski \& Owens (1982).

Flow cytometric DNA determination. Unconcentrated samples $(1 \mathrm{ml})$ were fixed with $1 \%$ glutaraldehyde (electron microscopy grade; Merck, Darmstadt, Germany), incubated for $10 \mathrm{~min}$ at room temperature in the dark, frozen in liquid nitrogen (Vaulot et al. 1989), and then stored at $-80^{\circ} \mathrm{C}$. Prior to analysis, samples were thawed at room temperature, stained with DAPI to a final concentration of $1 \mu \mathrm{g} \mathrm{ml}^{-1}(3.6 \mu \mathrm{M}$, cultures) or $2 \mu \mathrm{g} \mathrm{ml} \mathrm{m}^{-1}(7.2 \mu \mathrm{M}$, natural samples) and incubated for $90 \mathrm{~min}$ at room temperature in the dark. Calf thymocyte nuclei (Fluorotrol RF; Ortho Diagnostic System, Inc., Westwood, Massachusetts) and $2 \mu \mathrm{m}$ low-intensity Nile Red beads (Pandex, Mundelein, Illinois) were used as external (cultures) or internal (natural samples) standards.

For each sample 100 to $300 \mu$ were analyzed on an Epics 541 (Coulter) flow cytometer fitted with a $6 \mathrm{~W}$ argon laser (Model 90-6; Coherent, Palo Alto, California) and a Biosense flow cell. Laser emission was set at $351 / 364 \mathrm{~nm}$ (UV mode) and $100 \mathrm{~mW}$ (cultures) or $200 \mathrm{~mW}$ (natural samples). Scattered light (a sizing parameter) was measured at forward (FALS) and right (RALS) angles. RALS was collected after reflection on a $400 \mathrm{~nm}$ long-pass (LP) dichroic filter (MTO. France). Emitted fluorescence was filtered through a $415 \mathrm{~nm}$ LP filter (Coulter) and split with a $590 \mathrm{~nm}$ short-pass dichroic filter (Coulter) to separate blue DAPI-DNA fluorescence, collected through a $485 \mathrm{~nm}$ band-pass filter (Glen Spectra, Stanmore, UK), and red chlorophyll fluorescence, collected through a $690 \mathrm{~nm}$ LP filter (MTO). All 4 parameters (FALS, RALS, blue DAPI-DNA and red chlorophyll fluorescences) were recorded in peak (culture) or integral (for improved sensitivity in natural samples) mode on 3-decade logarithmic range (256 channels). Natural samples were recorded in list mode. Data were processed on an IBM-PC-compatible microcomputer using customdesigned software, CytoPC. Briefly, each picoplankton population (prochlorophytes, Synechococcus spp., eukaryotes; see 'Results') was identified by its flow cytometric signature on light-scatter vs chlorophyll cytograms and discriminated from the others by a rectangular gate. Its DNA histogram was obtained by playing back the list mode data and keeping only the cells that fell within the gate. From this histogram, the average DAPI-DNA fluorescence of the population was computed, all cell cycle stages being included, and was normalized to the fluorescence of the calf thymocyte nuclei.

\section{RESULTS AND DISCUSSION}

\section{Phytoplankton DNA staining for flow cytometry}

The first step in developing a DNA staining method for natural phytoplankton populations was to find an appropriate fixative. Its functions are (1) to preserve the cells so as to allow delayed analysis, (2) to preserve chlorophyll red fluorescence in order to differentiate photosynthetic cells from other particles, and (3) to make the cell membrane permeable so as to facilitate stain penetration. In cell cycle studies, alcohol preservation (methanol or ethanol) is by far the most widespread technique, but it cannot be used for natural populations since it extracts photosynthetic pigments (Olson et al. 1983). A method combining $1 \%$ glutaraldehyde fixation and liquid nitrogen freezing has been recently shown to preserve phytoplankton adequately for flow cytometric analyses (Vaulot et al. 1989). Preliminary tests showed that cells preserved with this method were amenable to DNA staining.

The second step was to choose a fluorescent DNA stain among the dozen available (Shapiro 1985), meeting several criteria. First, the fluorescence emission wavelengths of the stain and of the photosynthetic pigments must be distinct, so that the 2 fluorescences can be separated optically. A significant overlap of the emission bands results in a strong correlation of the 2 emitted fluorescences (cross-talk). This phenomenon prevents the use of red-emitting stains (e.g. propidium iodide) for chlorophyll-containing cells, and that of orange-emitting ones (e.g. chromomycin A3) for phycoerythrin-containing cells (cyanobacteria, Cryptophyceae). Second, the stain must bind stoichiometrically to DNA over the wide range of cell DNA content encountered in phytoplankton (typically from 0.1 to $100 \mathrm{pg}$ cell $^{-1}$; Holm-Hansen 1969a). Stoichiometry is also essential for cell cycle studies when cells in $G_{1}$ have to be distinguished from those in $\mathrm{G}_{2}+\mathrm{M}$ (Olson et al. 1983). Third, the fluorescence yield of the stain must be large enough to allow for analysis of the small picoplankton populations which dominate in most natural samples. With these criteria in mind, DAPI seemed to be a good choice. It is specific for DNA and does not require treatment with RNAse, in contrast to propidium iodide, which binds to both RNA and DNA (Shapiro 1985). Its emission peak (around $460 \mathrm{~nm}$ ) clearly falls out of both phycoerythrin and chlorophyll emission bands. It has a high fluorescence yield and as such has been recently used to stain the small bacteria encoun- 


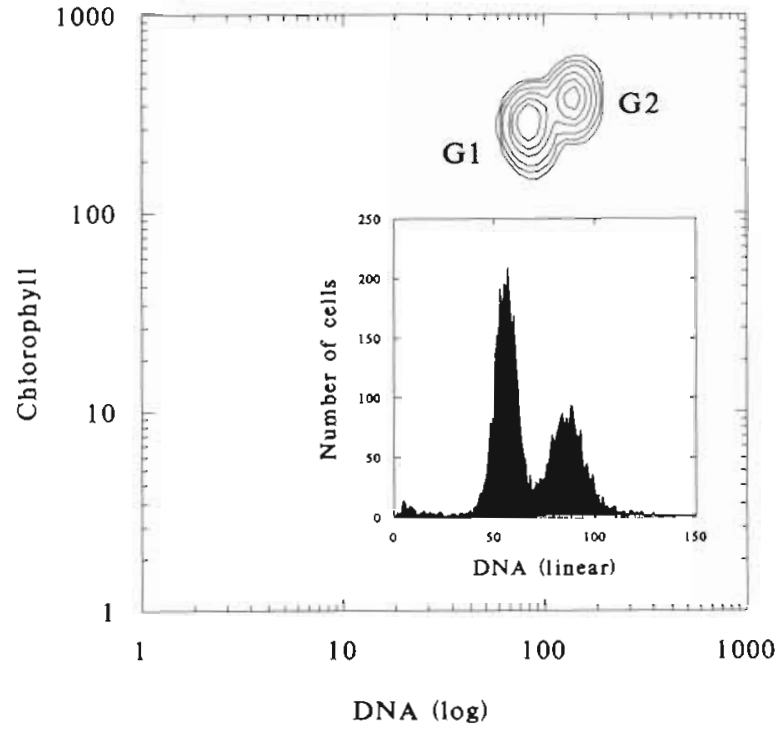

Fig. 1. Thalassiosira weissflogii. Flow cytometric analysis of the diatom fixed with $1 \%$ glutaraldehyde, frozen in liquid nitrogen, and stained with $1 \mu \mathrm{g} \mathrm{mI} \mathrm{m}^{-1}$ of DAPI. Contoured cytogram: distribution of red chlorophyll fluorescence vs DAPI-DNA fluorescence, both on 3-decade logarithmic scales. The 2 populations correspond to the $G_{1}$ and $G_{2}+M$ phases of the cell cycle. Insert: DNA distribution on a linear scale

tered in aquatic systems (Robertson \& Button 1989). One drawback of DAPI is that its affinity for DNA depends on the base pair composition, since it binds specifically to AT pairs (Lin et al. 1977).

We settled therefore for the following procedure: $1 \%$ glutaraldehyde fixation (final $\mathrm{pH}=6.6$ ), freezing in liquid nitrogen, and staining with $1 \mu \mathrm{g} \mathrm{ml}^{-1} \mathrm{DAPI}$. This protocol was found to stain all species effectively. Fluorescence was well above background, as the blue autofluorescence of cells in a non-stained sample never exceeded $5 \%$ of that of stained cells. Saturation was reached within $1 \mathrm{~h}$. There was no detectable interference between chlorophyll and DAPI fluorescences, as demonstrated by the absence of correlation between the 2 parameters in cytograms (Fig. 1). The coefficient of variation (CV) of the $\mathrm{G}_{1}$ peak ranged from 10 to $36 \%$ (average $=19.5 \%, \mathrm{n}=11$ ), with the worst results obtained for Synechococcus sp. Although we were able to resolve the $G_{1}$ and $G_{2}$ peaks in most cases (Fig. 1), the $\mathrm{CVs}$ obtained with this method were larger than those obtained with methanol fixation. For example, we obtained a CV of $13.4 \%$ for Thalassiosira weissflogii, while Vaulot et al. (1986) reported a CV of $6.5 \%$ with the latter method. Large CVs are probably a consequence of imperfect stain penetration rather than absorbance of DAPI fluorescence by chlorophyll, as suggested by Olson et al. (1983); the latter phenomenon would induce a negative correlation between chlorophyll and DAPI fluorescences, never observed in our case.
Absence of fixation or of cell freezing at low temperature resulted in very poor stain penetration, as observed previously (Olson et al. 1983). Fixation with either buffered glutaraldehyde $(\mathrm{pH}=7.5)$ or paraformaldehyde often resulted in lower DAPI-DNA fluorescence yields. The improvement at low $\mathrm{pH}$ is probably due to partial removal of histones (Giangarè et al. 1989).

In most species, stain penetration was facilitated by treatment of the cell membrane with detergent $10.1 \%$ Triton X100; Traganos et al. 1977). This increased DAPI-DNA fluorescence up to $30 \%$ and separated the $\mathrm{G}_{1}$ and $\mathrm{G}_{2}$ peaks better. Detergent treatment induced extrusion of cytoplasmic material and cell aggregation in some cases (e.g. Dunaliella primolecta) and was therefore not applicable to all species.

\section{Standardization and calibration}

In order to relate single-cell DAPI-fluorescence to cell DNA content, flow cytometric fluorescence measurements must first be standardized in order to eliminate day-to-day variations in instrument optimization. This is usually achieved with fluorescent beads. In the present case, reference cell nuclei are more indicated since they will also reflect day-to-day variations in staining conditions. We employed calf thymocyte nuclei, which are widely used and commercially available. It would also have been possible to use a given phytoplankton species to standardize all the others. When few samples are analyzed (e.g. cultures), reference cells can be used as external standards, provided they are stained under exactly the same conditions as the cells (i.e. in the present case in seawater with $1 \%$ glutaraldehyde). When a large number of samples are

Table 2. Cultured species: diameters, measured with a Coulter Counter, and DNA content, measured with DAPI by fluorometry. DNA content is the average over all cell cycle phases and not that of $G_{1}$ phase cells

\begin{tabular}{|lcc|}
\hline Species & $\begin{array}{c}\text { Diameter } \\
(\mu \mathrm{m})\end{array}$ & $\begin{array}{c}\text { DNA content } \\
\left.(\mathrm{pg} \mathrm{cell})^{-1}\right)\end{array}$ \\
\hline Synechococcus ROS04 & $1.5^{\mathrm{a}}$ & 0.027 \\
Synechococcus WH7803 & $1.5^{\mathrm{a}}$ & 0.022 \\
Cryptomonas maculata & 7.8 & 1.5 \\
Amphidinium carteri & 6.7 & 6.5 \\
Gymnodinium cf. nagasakiense & 19.4 & 71 \\
Gymnodinium nagasakiense & 21.1 & 123 \\
Isochrysis galbana & 4.0 & 0.42 \\
Hymenomonas carterae & 8.6 & 1.72 \\
Phaeocystis pouchetii & 5.1 & 0.43 \\
Thalassiosira weissflogii & 15.0 & 4.70 \\
Dunaliella primolecta & 5.9 & 0.72 \\
anstimated & & \\
& & \\
\hline
\end{tabular}



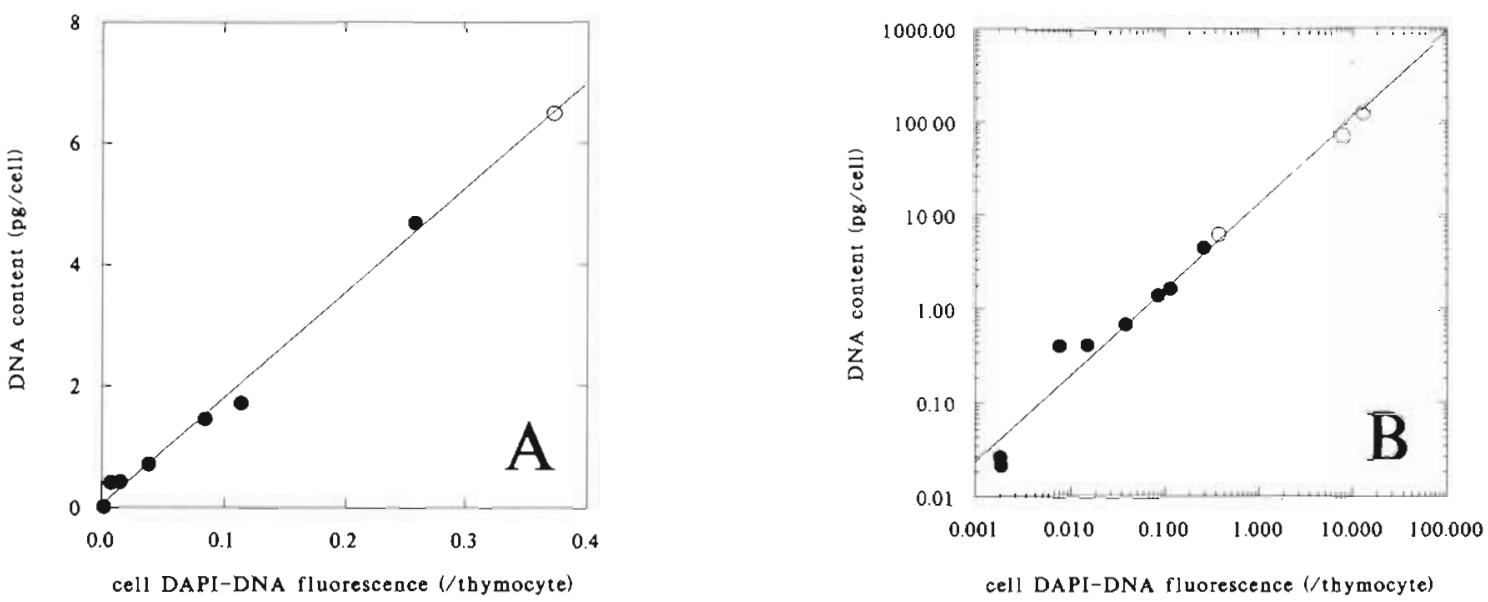

Fig. 2. Cell DAPI-DNA fluorescence measured by flow cytometry (normalized to calf thymocyte nuclei; per thymocyte) vs cell DNA content ( $\mathrm{pg} \mathrm{cell}^{-1}$ ), measured by fluorometry for different phytoplankton strains (Tables $1 \& 2$ ). (A) Linear scale (n $=9$ ). (B) Logarithmic scale $(n=11)$. Regression lines are given in the text by Eqs. (1) and (2), respectively. Open symbols correspond to dinoflagellates

to be run (natural populations), it is simpler to use them as internal standards, i.e. mixed with the sample.

In order to calibrate standardized flow cytometric measurements, we compared them to cellular DNA concentrations (DNA $A_{c}$ in pg cell ${ }^{-1}$ ) established by fluorometry using DAPI (Falkowski \& Owens 1982) for 11 strains of phytoplankton (Table 2). On a linear scale, we found a very good correlation between the 2 measurements in the range 0 to $7 \mathrm{pg}$ cell ${ }^{-1}$ for $D N A_{c}$, excluding the 2 Gymnodinium species, which have a very high DNA content (Fig. 2A):

$$
D N A_{\mathrm{c}}=17.4 \times D N A_{\mathrm{f}}+0.06 \quad\left(\mathrm{r}^{2}=1.00, \mathrm{n}=9\right)
$$

where $D N A_{\mathrm{f}}$ is blue DAPI-DNA fluorescence standardized to that of calf thymocyte nuclei.

Since $D N A_{c}$ spanned almost 4 orders of magnitude for the set of strains considered (Table 2), it appeared appropriate to plot these data on logarithmic scales (Fig. 2B):

$$
D N A_{\mathrm{c}}=13.9 \times D N A_{\mathrm{f}}^{0.92} \quad\left(\mathrm{r}^{2}=0.99, \mathrm{n}=11\right)
$$

The good correlations obtained in both cases indicate that, provided the same stain is used (DAPI), the flow cytometric method, for which DNA is maintained packaged inside the cells, and the fluorometric method, for which the DNA is extracted, yield very comparable results. The slight non-linearity of Eq. (2) (exponent = 0.92 instead of 1) indicates that larger cells are more readily stained than smaller cells. It is noteworthy that dinoflagellates, although their DNA structure is very different from that of the other eukaryotes (Rizzo 1987), did not depart from the regression line. If $D N A_{\mathrm{f}}$ is set equal to $1, D N A_{c}$ is equal to 17.5 (Eq. 1) or 13.9 (Eq. 2) pg cell ${ }^{-1}$, which should represent the DNA content of the thymocytes. It is higher, however, than the actual value (7.3 pg cell ${ }^{-1}$; Tiersch et al. 1989) and reflects the fact that bare thymocyte nuclei are more easily stained than glutaraldehyde-fixed phytoplankton cells.

As mentioned earlier, DAPI fluorescence is a function of both absolute DNA content and base pair composition. Therefore, if instead of measuring cell DNA fluorometrically with DAPI we had measured it with a stain which is not base-sensitive, such as 3,5diaminobenzoic acid (DABA; Holm-Hansen 1969a) or ethidium bromide, we would have observed a lower correlation with the flow cytometric measurements, since base composition varies widely in phytoplankton

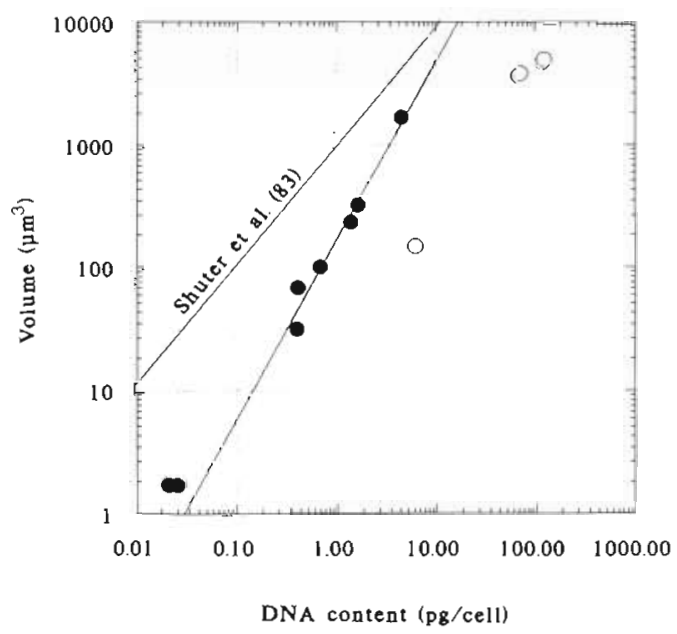

Fig. 3. Cell DNA content measured by flurometry vs cell volume for 11 phytoplankton strains (Tables $1 \& 2$ ). Regression line is given in the text by Eq. (3) and does not include prokaryotes (Synechococcus sp., 2 points at lower left) nor dinoflagellates (open symbols). The other line corresponds to the relation established by Shuter et al. (1983) 
even within a single species. For example, in Chlorella sorokiniana $\mathrm{G}+\mathrm{C}$ content varies between 61.5 and 75.2\% (Huss et al. 1986).

Mean cell volume $\left(V\right.$, in $\left.\mu \mathrm{m}^{3}\right)$ was found to be well correlated with cell DNA content, if prokaryotes and Dinophyceae were excluded (Fig. 3):

$$
V=164 \times D N A_{\mathrm{c}}{ }^{1.46} \quad\left(\mathrm{r}^{2}=0.97, \mathrm{n}=6\right)
$$

Such a relation is qualitatively similar to that established by Shuter et al. (1983) for a wide range of unicellular eukaryotes and suggests that DNA might be a good estimator of phytoplankton biomass. Part of the discrepancy between our data (Fig. 3) and those of Shuter et al. (1983) could come from the heterogeneity of their data set, where cell volume and cell DNA have often been obtained from different investigators. Prokaryotes were not included in Eq. (3), because they exhibit a volume-to-DNA relation very different from that of eukaryotes (Shuter et al. 1983). The latter authors also found that dinoflagellates fitted well to the eukaryotic relation, while our data indicate that the volume: DNA ratio was 10 times smaller for dinoflagellates than for other species. Although more measurements are clearly needed before drawing definitive conclusions, our data are actually consistent with the fact that this algal class is well known for its large number of chromosomes and its high proportion of structural DNA, which compensates for the low abundance of nuclear histone-like proteins (Rizzo 1987). Moreover, DNA content may vary widely among dinoflagellate species of similar size. This is the case with the morphologically similar taxa Gymnodinium nagasakiense, widespread in Japanese waters, and Gymnodinium cf. nagasakiense, common in European seas, which exhibit a 2 -fold discrepancy in DNA contents (Table 2) despite equivalent numbers of chromosomes (Partensky et al. 1988).

\section{Application to natural populations}

Several problems may arise when a staining method, tested on cultures, is applied to natural populations. First, cells can be lost due to fixation and preservation. In the present case, however, the fixation method has been extensively tested on natural and cultured populations and appears to induce minimal cell loss, except for some fragile phytoplankton classes such as cryptophytes and dinoflagellates (Vaulot et al. 1989). In contrast, alcohol fixation, which requires several rounds of centrifugation, results in over $90 \%$ cell loss (D. Vaulot unpubl.). Second, natural samples contain a whole array of particles that might be stained nonspecifically by the fluorochrome and interfere with detection of the cells of interest. Third, species that are

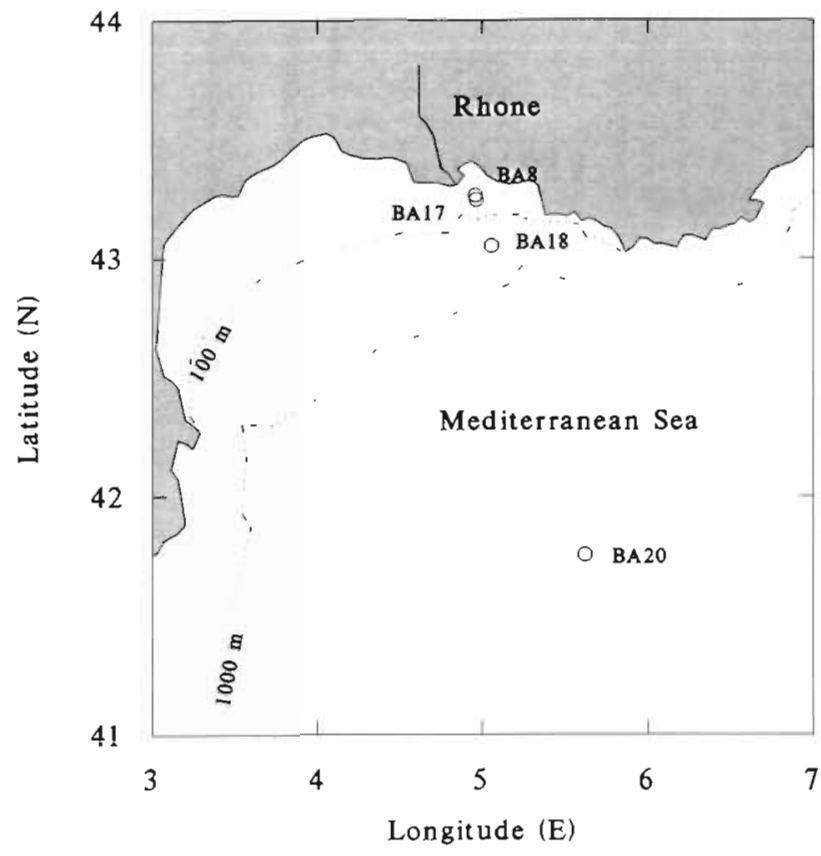

Fig. 4. Stns BA8, BA17, BA18 and BA20, sampled in the northwestern Mediterranean Sea in July 1989

maintained in culture are not fully representative of those that thrive in the oceans (Giovannoni et al. 1990), and the response of the most fragile species can only be tested with natural samples.

To examine these potential problems, the method was tested on natural picoplankton populations from samples taken in summer at 4 stations located on an offshore transect in the northwestern Mediterranean Sea (Fig. 4). In a typical sample, 3 picoplankton populations of increasing cell size and decreasing abundance were usually present: prochlorophytes (Chisholm et al. 1988), Synechococcus spp. cyanobacteria, and picoeukaryotes (Fig. 5A). The identity of each group was established by parallel flow cytometric analysis of the sample using visible light $(488 \mathrm{~nm})$ and, for the prochlorophytes, by spectrofluorometric pigment analysis (Vaulot et al. 1990). The 3 populations were stained correctly by our procedure (Fig. 5B). Non-living particles and bacteria proved not to be a major problem: although they interfered with prochlorophytes in ungated cytograms (Fig. 5B), they could be easily removed by gating the picoplankton populations on the scatter vs chlorophyll cytograms (Fig. 5C). As in cultured populations, there was no interference between DAPI-DNA and chlorophyll fluorescences, as visualized by the absence of correlation between the 2 parameters in the corresponding cytograms (Fig. 5C). Eukaryotes were usually composed of 2 sub-populations. One gave sharp DNA distributions with CVs as low as $9 \%$ (Fig. 5C and middle eukaryotic peak in Fig. 

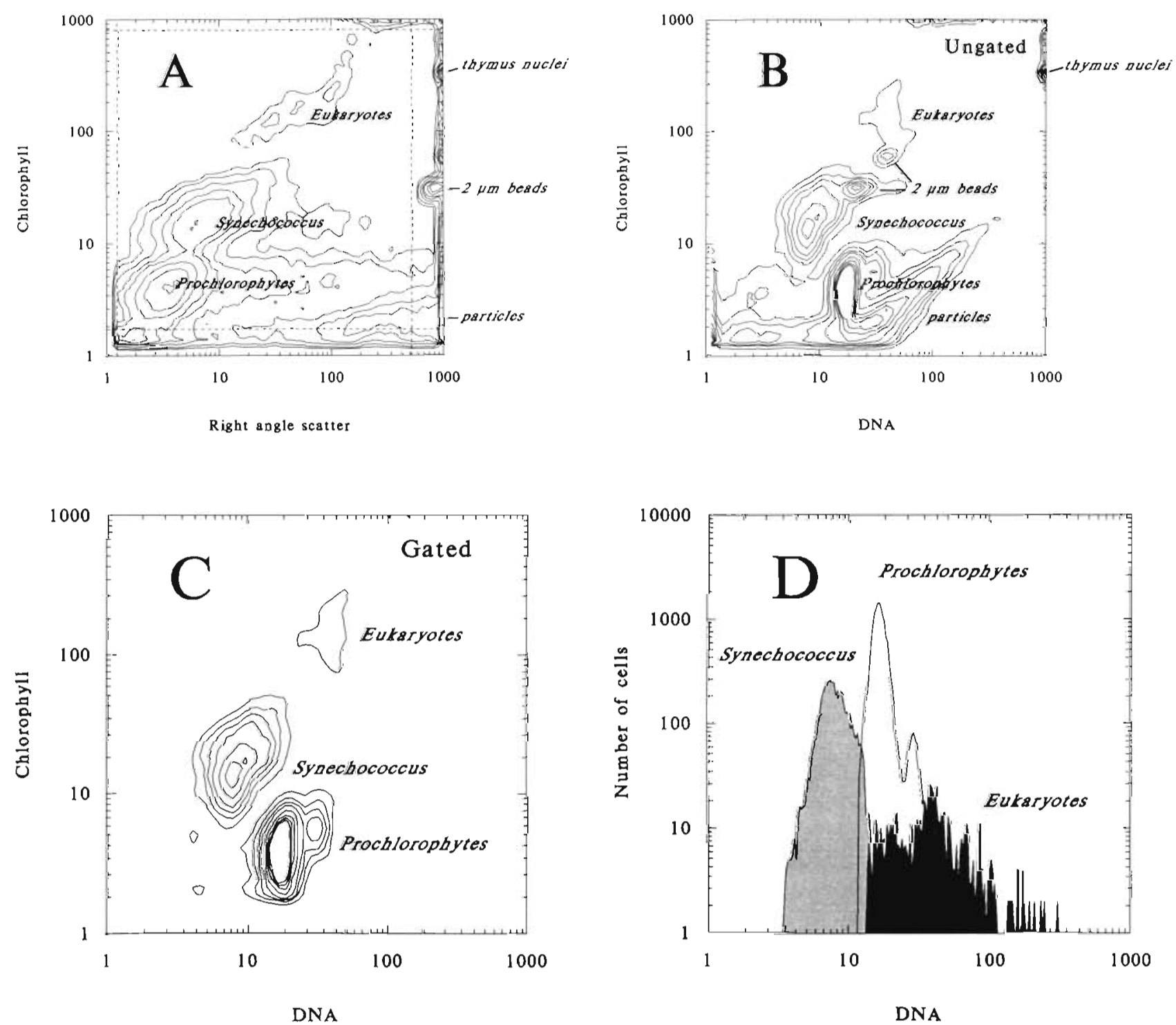

Fig. 5. Phytoplankton sampled from Stn BA18, $55 \mathrm{~m}$ depth, in the northwestern Mediterranean Sea. (A) Cytogram of right angle light scatter (sizing parameter) vs chlorophyll fluorescence (log units, 3 decades). Three cell populations are visible: prochlorophytes (46800 cell ml $\mathrm{m}^{-1}$ ), Synechococcus spp. cyanobacteria $\left(16600 \mathrm{cell} \mathrm{m} l^{-1}\right)$, and picoeukaryotes $\left(2370 \mathrm{cell} \mathrm{ml}^{-1}\right)$. The population on the lower right-hand side with large scatter and low fluorescence is composed of detrital particles. Calf thymocyte nuclei and $2 \mu \mathrm{m}$ beads have been added as internal standards. The dashed rectangle represents a gating region containing only photosynthetic picoplankton. (B) Cytogram of DAPI-DNA fluorescence vs chlorophyll fluorescence (log units, 3 decades). Note interference between the particles and the prochlorophytes. The apparent high red fluorescence of the thymocyte nuclei is a consequence of their very high blue DAPI fluorescence (it would fall around 10000 , out of scale, on the $\mathrm{x}$-axis), which leaks into the red channel. (C) Same as (B) but only for populations contained within the gate drawn in (A). Note that gating removed the interfering particles as well as the $2 \mu \mathrm{m}$ beads and the thymocyte nuclei. (D). DNA histograms for the different cell populations. Note that vertical axis is in $\log$ units. Picoplankton. DNA concentration was estimated, using Eq. (2), to be equal to $2.3 \mu \mathrm{g} \mathrm{l}^{-1} \mathrm{in}$ this sample

5D) and probably was constituting a single taxonomic entity; the other had a broad DNA distribution and was likely a mixture of several cell types. Synechococcus spp. had DNA distributions with non-distinct peaks and CVs on the order of $25 \%$, similar to those observed for cultures (Fig. 5D). The very small prochlorophytes (0.4 to $0.8 \mu \mathrm{m}$ in diameter) produced a very good DNA signal with sharp peaks having CVs on the order of $10 \%$ (Fig. 5D). Their DAPI-DNA fluorescence was actually more intense than for Synechococcus spp. despite the larger size of the latter (Fig. 5A). Although prochlorophytes could have a larger DNA content (and likely a larger DNA: C ratio) or be richer in AT base pairs, this was probably a consequence of easier stain 
penetration in prochlorophytes: Synechococcus spp. cyanobacteria are notorious for their very tough membrane (Bricaud et al. 1988), and while Triton X100 treatment increases stain penetration in Synechococcus sp., it lyses prochlorophytes (data not shown).

Using Eq. (2) to convert DAPI-DNA fluorescence to DNA content for each population, photosynthetic picoplankton DNA was estimated and compared to total particulate DNA (Table 3). It must be stressed that these estimates are not fully representative of the total phytoplankton community since they do not include the larger plankton (typically $>2 \mu \mathrm{m}$ ), which was probably in significant concentration near the coast (in surface samples, cells $>1 \mu \mathrm{m}$ accounted for $85 \%$ of the chlorophyll $a$ at Stn BA8 and for $62 \%$ at Stn BA18; J. Neveux pers. comm.). The relative contribution of the 3 picoplanktonic groups was variable: prochlorophytes dominated at the 3 stations closer to shore, and Synechococcus at the outermost station BA20 (Table 3). In some cases, we obtained unreasonably high estimates of picoplankton DNA (e.g. Stn BA18, $55 \mathrm{~m}$ ), which might be due to an overestimate of prochlorophyte DNA because of their good stainability (see above).

When all samples were pooled together, no correlation was observed between total particulate DNA and picoplankton DNA $\left(\mathrm{r}^{2}=0.036, \mathrm{n}=28, \mathrm{P}=0.331\right)$, in agreement with previous studies that failed to find any significant relation between particulate DNA and chlorophyll (Holm-Hansen 1969b, Paul et al. 1985). This points out the highly variable contribution of phytoplankton to particulate organic matter. A clearer pattern emerged if neritic and pelagic stations were contrasted (Table 3). At neritic stations (BA8, BA17) picoplankton accounted for a higher proportion of particulate DNA, in accordance with the observations of Falkowski \& Owens (1982) and Paul et al. (1985). At pelagic stations (BA18, BA20) picoplankton contribution was in general lower, especially in the upper euphotic zone and at depth, while it peaked at the picoplankton maximum. This corroborates previous reports (Paul et al. 1985, Winn \& Karl 1986, Fuhrman et al. 1989, Cho \& Azam 1990) asserting that, in oligotrophic waters, phytoplankton is a small fraction of the total living biomass.

\section{CONCLUSION}

The method described in this paper should permit quantitative determination of DNA in single phytoplankton cells. It is much more informative than total particulate DNA measurements, since it allows assessment of how DNA is partitioned among the different compartments of the food web. In the present study, we restricted ourselves to picoplankton. However, flow cytometry and DAPI staining have already helped characterize bacterial communities (Robertson \& Button 1989) and can certainly be applied to larger phytoplankton ( $>2 \mu \mathrm{m}$ ) and microzooplankton, using instruments designed to handle larger sample volumes (Dubelaar et al. 1989).

One source of error in cell DNA estimates by flow cytometry may arise from differences in stain penetration among species. Although this was not observed in cultures, as evidenced by the very good fit obtained for Eq. (2), we suspect that it occurred for field populations, in particular for prochlorophytes, which had a much higher DAPI fluorescence than expected on the basis of their size. Therefore, calibration should be performed using cultured species as closely related as possible to the field populations of interest.

A supplemental source of error comes from the base specificity of DAPI. Consider a cell population whose

Table 3. Mean \pm SD of total particulate DNA (measured by fluorometry) and DNA in 3 photosynthetic picoplankton populations (measured by flow cytometry and computed as detailed in text) in different depth strata in the northwestern Mediterranean Sea in July 1989 (Fig. 4). For neritic stations (BA8, BA17), where there was no definite pattern in the vertical distribution of picoplankton DNA, all depths were pooled together. For pelagic stations (BA18, BA20), 3 layers were distinguished: upper euphotic zone, picoplankton maximum, and below the picoplankton maximum

\begin{tabular}{|c|c|c|c|c|c|c|c|}
\hline Stn & $\begin{array}{l}\text { Depth } \\
\text { stratum } \\
\text { (m) }\end{array}$ & $\begin{array}{c}\text { Particulate } \\
\text { DNA } \\
\left(\mu \mathrm{g} \mathrm{l}^{-1}\right)\end{array}$ & $\begin{array}{c}\text { Prochlorophyte } \\
\text { DNA } \\
\left(\mu \mathrm{g} \mathrm{l}^{-1}\right)\end{array}$ & $\begin{array}{c}\text { Synechococcus spp. } \\
\text { DNA } \\
\left(\mu \mathrm{g}^{-1}\right)\end{array}$ & $\begin{array}{c}\text { Picoeukaryotes } \\
\text { DNA } \\
\left(\mu g l^{-1}\right)\end{array}$ & $\begin{array}{c}\text { Picoplankton } \\
\text { DNA } \\
(\%)\end{array}$ & $\mathrm{n}$ \\
\hline $\mathrm{BA} 8^{\mathrm{a}}$ & $5-70$ & $3.2 \pm 2.5$ & $1.00 \pm 0.35$ & $0.30 \pm 0.19$ & $0.53 \pm 0.48$ & $68 \pm 18$ & 3 \\
\hline BA 17 & $8-70$ & $2.4 \pm 1.4$ & $0.88 \pm 0.17$ & $0.19 \pm 0.06$ & $0.28 \pm 0.06$ & $74 \pm 44$ & 4 \\
\hline \multirow[t]{3}{*}{ BA18 } & $0-15$ & $2.6 \pm 1.0$ & $0.13 \pm 0.06$ & $0.10 \pm 0.01$ & $0.24 \pm 0.07$ & $20 \pm 7$ & 3 \\
\hline & 55 & 2.0 & 1.70 & 0.31 & 0.26 & 110 & 1 \\
\hline & $145-295$ & $13.7 \pm 2.7$ & $0.01 \pm 0.00$ & $0.01 \pm 0.01$ & $0.02 \pm 0.01$ & $0 \pm 0$ & 2 \\
\hline \multirow[t]{3}{*}{$\mathrm{BA} 20$} & $5-30$ & $6.5 \pm 3.6$ & $0.28 \pm 0.12$ & $0.28 \pm 0.13$ & $0.30 \pm 0.04$ & $14 \pm 3$ & 3 \\
\hline & 50 & 8.3 & 0.42 & 1.74 & 0.45 & 31 & 1 \\
\hline & $75-100$ & $8.7 \pm 4.3$ & $0.00 \pm 0.00$ & $0.05 \pm 0.05$ & $0.06 \pm 0.04$ & $1 \pm 0$ & 2 \\
\hline
\end{tabular}


contribution to particulate DNA is $D_{1}\left(\mu \mathrm{g} \mathrm{l}^{-1}\right)$ and whose AT base composition is $f_{1}$ (a number between 0 and 1). $D_{2}$ and $f_{2}$ correspond to the rest of the living biomass. Assuming that $D_{2} \gg D_{1}$, i.e. that the cell population is only a small fraction of the total biomass, and that the fluorescence of DAPI is proportional to the product $f_{\mathrm{i}} D_{1}$ (although this might be an oversimplified assumption, as it has been recently shown that DAPI binds to a consensus of 4 consecutive AT base pairs; Portugal \& Waring 1988), then the flow cytometric estimate of the fraction of DNA contained in the cell population would be equal to $f_{1} D_{1} / f_{2} D_{2}$, while the actual value is $D_{1} / D_{2}$. The maximum range of variation for the AT fraction among all living organisms lies between 0.20 and 0.80 (Stanier et al. 1970). If we take the median of this range for $f_{2}(0.5)$, the flow cytometric estimate would fall between 0.4 and 1.6 times the actual value.

Despite these limitations, the linear relation registered between cell volume and DNA (Eq.3) indicates that the latter could be used to estimate biomass, once rigorous calibration has been performed. Future studies should compare such estimates with carbon estimates.

The use of DNA in flow cytometric analyses of natural picoplankton populations may also help assess their heterogeneity in conjunction with other cell properties such as pigment fluorescence characteristics (Olson et al. 1988), antibody-binding (Shapiro et al. 1989), or oligonucleotide-tagging (Amann et al. 1990). For example, prochlorophytes and Synechococcus spp. are better separated on DNA vs chlorophyll cytograms (Fig. 5C) than on scatter vs chlorophyll (Fig. 5A). Increased separation might also be obtained by using, in conjunction with the AT-binding DAPI, a GC-binding dye such as chromomycin A3 (Van Dilla et al. 1983).

Another benefit of measuring single-cell DNA in natural populations is to gain information on their cell cycle status. Numerous laboratory studies have investigated how the cell cycle of marine and freshwater phytoplankton is controlled by environmental factors such as light, temperature, or nutrients (cf. reviews in Puiseux Dao 1981, Donnan et al. 1985). However, these controls have never been demonstrated in the field. The very good staining ability of the prochlorophytes (see above) enabled us to actually analyze their cell cycle in natural samples and to demonstrate its control by nitrogen in situ (Vaulot \& Partensky unpubl.). For other cell types such as Synechococcus sp. (Fig. 5), our procedure will have to be improved (e.g. by detergent addition) to yield a better definition of the cell cycle phases. Flow cytometric measurements of DNA in natural phytoplankton populations will facilitate the application of a recently developed method to derive growth rates of synchronized populations from time series of DNA distributions (Carpenter \& Chang 1988), providing a datum much sought after to resolve the long-standing controversy about the exact magnitude of phytoplankton growth rates in oligotrophic waters (Goldman et al. 1979).

Acknowledgements. Help from Claude Courties and JeanLouis Birrien is kindly acknowledged, as well as constructive comments from 2 referees. The EPICS 541 was funded by the Institut National des Sciences de l'Univers (CNRS). Financial support for field work was provided by the Commission of the European Communities 4th Environment R\&D Programme under contract EV4V-011-F (EROS-2000 Project).

\section{LITERATURE CITED}

Amann, R. I., Binder, B. J., Olson, R. J., Chisholm, S. W., Devereux, R., Stahl, D. A. (1990). Combination of $16 \mathrm{~S}$ rRNA-targeted oligonucleotide probes with flow cytometry for analyzing mixed microbial populations. Appl. environ. Microbiol. 56: 1919-1925

Bricaud, A., Bédhomme, A.-L., Morel, A. (1988). Optical properties of diverse phytoplanktonic species: experimental results and theoretical interpretation. J. Plankton Res. 10: 851-873

Brunk, C. F., Jones, K. C., James, T. W. (1979). Assay for nanogram quantities of DNA in cellular homogenates. Analyt. Biochem. 92: 497-500

Carpenter, E. J., Chang, J. (1988). Species-specific phytoplankton growth rates via diel DNA synthesis cycles. I. Concept of the method. Mar. Ecol. Prog. Ser. 43: 105-111

Chisholm, S. W., Olson, R. J., Zettler, E. R., Waterbury, J., Goericke, R., Welschmeyer, N. (1988). A novel free-living prochlorophyte occurs at high cell concentrations in the oceanic euphotic zone. Nature, Lond. 334: 340-343

Cho, B. C., Azam, F. (1990). Biogeochemical significance of bacterial biomass in the ocean's euphotic zone. Mar. Ecol. Prog. Ser. 63: 253-259

Donnan, L., Carvill, E. P., Gilliland, T. J., John, P. C. L. (1985). The cell cycles of Chlamydomonas and Chlorella. New Phytol. 99: 1-40

Dortch, Q., Roberts, T L., Clayton, J. R. Jr, Ahmed, S. I. (1983). RNA/DNA ratios and DNA concentrations as indicators of growth rate and biomass in planktonic marine organisms. Mar. Ecol. Prog. Ser. 13: 61-71

Dubelaar, G. B., Groenewegen, A. C., Stokdijk, W., van den Engh, G. J., Visser, J. W. (1989). Optical plankton analyser: a flow cytometer for plankton analysis. II. Specifications. Cytometry (N.Y.) 10: 529-539

Falkowski, P. G., Owens, T. C. (1982). A technique for estimating phytoplankton division rates by using a DNA-binding fluorescent dye. Limnol. Oceanogr. 27: 776-782

Fuhrman, J. A., Sleeter, T. D., Carlson, C. A., Proctor, L. M. (1989). Dominance of bacterial biomass in the Sargasso Sea and its ecological implications. Mar. Ecol. Prog. Ser. 57: 207-217

Giangarè, M. C., Prosperi, E., Pedraly-Noy, G., Bottiroli, G. (1989). Flow cytometric evaluation of DNA stainability with propidium iodide after histone $\mathrm{H} 1$ extraction. Cytometry (N.Y.) 10: 726-730

Giovannoni, S. J., Britschgi, T. B., Moyer, C. L., Field, K. G (1990). Genetic diversity in Sargasso Sea bacterioplankton. Nature, Lond. 345: 60-63

Goldman, J. C., McCarthy, J. J., Peavey, D. W. (1979). Growth rate influence on the chemical composition of phytoplankton in oceanic waters. Nature, Lond. 279:210-215 
Guillard, R. R., Ryther, J. H. (1962). Studies of marine diatoms. I. Cyclotella nana Husdedt and Detonula confervacea Gran. Can. J. Microbiol. 8: 229-239

Holm-Hansen, O. (1969a). Amount of DNA and organic carbon in single cells. Science 63: 87-88

Holm-Hansen, O. (1969b). Determination of microbial biomass in ocean profiles. Limnol. Oceanogr. 14: 740-747

Holn-Hansen, O., Sutcliffe, W. H. Jr, Sharp, J. (1968). Measurements of deoxyribonucleic acid in the ocean and its ecological significance. Limnol. Oceanogr. 13: 507-514

Huss, V. A. R., Dörr, R., Grossmann, U., Kessler, E. (1986). Deoxyribonucleic acid reassociation in the taxonomy of the genus Chlorella. I. Chlorella sorokiniana. Archs Microbiol. 145: 329-333

Karl, D. M., Bailliff, M. D. (1989). The measurement and distribution of dissolved nucleic acids in aquatic environments. Limnol. Oceanogr. 34: 543-558

Keller, M. D., Selvin, R. C., Claus, W., Guillard, R. R. L. (1987). Media for the culture of oceanic ultraphytoplankton. J. Phycol. 23: 633-638

Lin, M. S., Comings, D. E., Alfi, O. S. (1977). Optical studies of the interaction of 4'-6-diamino-2-phenylindole with DNA and melaphase chromosomes. Chromosoma 60: 15-25

Olson, R. J., Chisholm, S. W., Zettler, E. R., Armbrust, E. V. (1988). Analysis of Synechococcus pigment types in the sea using single and dual beam flow cytometry. Deep Sea Res. 35: 425-440

Olson, R. J., Frankel, S. L., Chisholm, S. W., Shapiro, H. M. (1983). An inexpensive flow cytometer for the analysis of fluorescence signals in phytoplankton: chlorophyll and DNA distributions. J. exp. mar. Biol. Ecol. 68: 129-144

Olson, R. J., Vaulot, D., Chisholm, S. W. (1985). Marine phytoplankton distributions measured using shipboard flow cytometry. Deep Sea Res. 32: 1273-1280

Partensky, F., Vaulot, D., Couté, A., Sournia, A. (1988). Morphological and nuclear analysis of the bloom forming dinoflagellates Gyrodinium cf. aureolum and Gymnodinium nagasakiense (Dinophyceae). J. Phycol. 24: 408-415

Paul, J. H., DeFlaun M. F., Jeffrey, W. H., David, A. W. (1988) Seasonal and diel variability in dissolved DNA and in microbial biomass and activity in a subtropical estuary. Appl, environ. Microbiol. 54: 718-727

Paul, J. H., Jeffrey, W. H., DeFlaun, M. (1985). Particulate DNA in subtropical oceanic and estuarine planktonic environments. Mar. Biol. 90: 95-101

Pillai, T. N. V., Ganguly, A. K. (1972). Nucleic acids in the dissolved constituents of sea-water. J. mar. biol. Ass. India 14: $384-390$

Portugal, J., Waring, M. J. (1988). Assignment of DNA binding sites to 4',6-diamidino-2-phenylindole and bisbenzimide (Hoechst 33258). A comparative footprinting study Biochim. biophys. Acta 949: 158-168

This article was presented by $M$. Levandowsky, New York, New York, USA
Prescott, D. M. (1976). Reproduction in eukaryotic cells Academic Press, New York

Puiseux Dao, S. (1981). Cell-cycle events in unicellular algae. In: Platt, T. (ed.) Can. Bull. Fish. Aquat. Sci. 210: 130-149

Rizzo, P. J. (1987). Biochemistry of the dinoflagellate nucleus. In: Taylor, F. J. R. (ed.) Botanical Monographs, Vol. 21, The biology of dinoflagellates. Blackwell Scientific Publications, Oxford, p. 143-173

Robertson, B. R., Button, D. K. (1989). Characterizing aquatic bacteria according to population, cell size, and apparent DNA content by flow cytometry. Cytometry (N.Y.) 10: $70-76$

Shapiro, H. M. (1985). Practical flow cytometry, Alan R. Liss Inc., New York

Shapiro, L. P., Campbell, L., Haugen, E. M. (1989). Immunochemical recognition of phytoplankton species. Mar. Ecol. Prog. Ser. 57: 219-224

Shuter, B. J., Thomas, J. E., Taylor, W. D., Zimmerman, A. M. (1983). Phenotypic correlates of genomic DNA content in unicellular eukaryotes and other cells. Am. Nat. 122: 26-44

Simon, M., Azam, F. (1989). Protein content and protein synthesis rates of planktonic bacteria. Mar. Ecol. Prog. Ser. 51: 201-213

Stanier, R. Y., Doudoroff, M., Adelberg, E. A. (1970). The microbial world, 3rd edn. Prentice Hall, Inc., Engelwood Cliffs, New Jersey

Tiersch, T. R., Chandler, R. W., Wachtel, S. S., Elias, S. (1989). Reference standards for flow cytometry and application in comparative studies of nuclear DNA content. Cytometry (N.Y.) 10:706-710

Traganos, F., Darzynkiewicz, Z., Sharpless, T., Melaned, M. R. (1977). Simultaneous staining of ribonucleic and deoxy. ribonucleic acids in unfixed cells using acridine orange in a flow cytofluorometric system. J. Histochem. Cytochem. 25: 46-56

Van Dilla, M. A., Langlois, R. G., Pinkel, D., Yajko, D., Hadley, W. K. (1983). Bacterial characterization by flow cytometry. Science 220: 620-622

Vaulot, D., Courties, C., Partensky, F. (1989). A simple method to preserve oceanic phytoplankton for flow cytometric analyses. Cytometry (N.Y.) 10: 629-635

Vaulot, D., Olson, R. J., Chisholm, S. W. (1986). Light and dark control of the cell cycle in two phytoplankton species. Expl. Cell Res. 167: 38-52

Vaulot, D., Partensky, F., Neveux, J., Mantoura, R. F. C. Llewellyn, C. (1990). Winter presence of prochlorophytes in surface waters of the northwestern Mediterranean Sea. Limnol. Oceanogr. 35: 1156-1164

Winn, C. D., Karl, D. M. (1986). Diel nucleic acid synthesis and particulate DNA concentrations: conflicts with division rate estimates by DNA accumulation. Limnol. Oceanogr. 31: $637-645$

Manuscript first received: July 30, 1990

Revised version accepted: January 24, 1991 